\title{
ANTIHEPATITIS C VIRUS ACTIVITY OF INDONESIAN MAHOGANY (TOONA SURENI)
}

\author{
ACHMAD FUAD HAFID ${ }^{1,2 *}$, TUTIK SRI WAHYUNI ${ }^{1,2}$, LIDYA TUMEWU $^{1}$, EVHY APRYANI ${ }^{1}$, ADITA \\ AYU PERMANASARI ${ }^{1}$, MYRNA ADIANTI ${ }^{1,3}$, CHIE AOKI UTSUBO $^{4}$, ATY WIDYAWARUYANTI ${ }^{1,2}$, MARIA INGE LUSIDA ${ }^{1}$, \\ SOETJIPTO $^{1}$, HIROYUKI FUCHINO ${ }^{6}$, NOBUO KAWAHARA ${ }^{6}$, HAK HOTTA ${ }^{5}$
}

${ }^{1}$ Institute of Tropical Disease, Universitas Airlangga, Surabaya, Indonesia. ${ }^{2}$ Department of Pharmacognosy and Phytochemistry, Faculty of Pharmacy, Universitas Airlangga, Surabaya, Indonesia. ${ }^{3}$ Department of Health, Study Program Traditional Medicine, Vocational Faculty, Universitas Airlangga, Surabaya, Indonesia. ${ }^{4}$ Department of International Health, Kobe University Graduate School of Health Sciences, 7-10-2, Tomogaoka, Suma-ku, Kobe 654-0142, Japan. ${ }^{5}$ Department of Oral Vaccine and Drug Development, Kobe University Graduate School of Health Sciences, 1-5-6 Minatojima-minamimachi, Chou-ku, Kobe 650-0047, Japan. ${ }^{6}$ Research Center for Medicinal Plant Resources, National Institute of Biomedical Innovation, Tsukuba, Ibaraki, Japan. Email: achmadfuad@ff.unair.ac.id,achmadfuad@yahoo.com

Received: 24 February 2017, Revised and Accepted: 27 October 2017

\section{ABSTRACT}

Objective: Toona sureni (Indonesian mahogany) is a member of Meliaceae family and locally known as suren. Previous study reported that T. sureni leaves extract exhibited antiviral activity with $50 \%$ inhibitory concentration ( $\mathrm{IC}_{50}$ ) value of $13.9 \pm 1.6 \mu \mathrm{g} / \mathrm{ml}$ against hepatitis $\mathrm{C}$ virus (HCV) J6/JFH1. Cytotoxicity analysis of $T$. sureni leaves extract did not reveal any cytotoxicity effect; therefore, further study was taken to investigate the active substances from the extract.

Methods: Bioassay-guided isolation of anti-HCV was conducted using Huh-7.5 cells infected with HCV J6/JFH1 in the presence of extracts, fractions, or compounds from the plant.

Results: Ethyl acetate fraction (Fr E) exhibited high anti-HCV activity with $\mathrm{IC}_{50}$ value of $1.7 \mu \mathrm{g} / \mathrm{ml}$. Further, separation of Fr E by open column chromatography resulted in nine sub-fractions (sub-Fr E1-E9). Sub-Fr E3 and E4 have IC ${ }_{50}$ value of $29.90 \mu \mathrm{g} / \mathrm{ml}$ and $7.68 \mu \mathrm{g} / \mathrm{ml}$, respectively. Polyphenols compounds have been isolated from sub-Fr E3 and E4. The structures have been determined to be ethyl gallate (1), methyl gallate (2), catechin (3), gallic acid (4), and quercetin 3-O-rhamnoside (5). Among the isolated compounds, gallic acid showed to possess strong anti-HCV activity with $\mathrm{IC}_{50}$ value of $15.9 \mu \mathrm{g} / \mathrm{ml}$.

Conclusion: T. sureni and its isolated compound, gallic acid, may be good candidates to develop for alternative and/or complementary agents of anti-HCV infection.

Keywords: Toona sureni, Leaves extract, Polyphenols, Antihepatitis C virus, Gallic acid.

(C) 2018 The Authors. Published by Innovare Academic Sciences Pvt Ltd. This is an open access article under the CC BY license (http://creativecommons. org/licenses/by/4. 0/) DOI: http://dx.doi.org/10.22159/ajpcr.2018.v11i2.18126

\section{INTRODUCTION}

Hepatitis $\mathrm{C}$ virus (HCV) is a major cause of liver disease and potential cause of substantial morbidity and mortality worldwide. Global prevention and control of HCV were met with difficulties due to the complexity and uncertainty related to the geographic distribution of HCV infection and chronic hepatitis $\mathrm{C}$, determination of its associated risk factors, and evaluation of cofactors that accelerate its progression. No vaccine is available to prevent HCV infection, nor does immune globulin provide protection $[1,2]$

Hepatitis $C$ is an RNA virus that mutates very rapidly, until now, there were seven genotypes (1-7) with more than 70 subtypes. HCV genome encodes structural protein (Core, E1, and E2) and non-structural protein (NS2, NS3, NS4A, NS4B, NS5A, and NS5B). Glycoproteins E1 and $\mathrm{E} 2$ were responsible for virus binding to the cell surface meanwhile the function of non-structural protein was RNA replication and virus particle construction [3-5]. The current standard interferon-free treatment regimens with a combination of direct-acting antiviral agents (DAAs) targeting the viral NS3 protease, NS5A multifunction protein, and NS5B RNA-dependent RNA polymerase result sustained virological responses $>90 \%$. However, the emergence of DAA-resistant HCV strains, limited access to the DAAs due to their high cost is also an important issue. Many therapies for HCV infection have been developed, but the therapeutic efficacy still needs to be improved [6]. In future, anti-HCV research should aim at the development of therapies for non-responder patient population and treatment regiments with short duration of treatment [7].

Many plants species are being tested for anti-HCV to find a possible cure for HCV. Some of them have shown significant inhibition in entry, replication, and assembly steps of the viral life cycle [8]. Moreover, some compounds have been isolated and tested for anti-HCV. Previous study reported that chalepin and pseudane IX which isolated from Ruta angustifolia leaves showed strong anti-HCV activities with 50\% inhibitory concentration (IC ${ }_{50}$ ) value of $1.7 \pm 0.5$ and $1.4 \pm 0.2 \mu \mathrm{g} / \mathrm{ml}$, respectively, without apparent cytotoxicity [9]. A major catabolite of chlorophyll A, which was isolated from Morinda citrifolia and identified as pheophorbide A, was reported to possess anti-HCV activity with $\mathrm{IC}_{50}$ value of $0.3 \mu \mathrm{g} / \mathrm{ml}$. It was reported also that pyropheophorbide $\mathrm{A}$ is an anti-HCV compound with $\mathrm{IC}_{50}$ value of $0.2 \mu \mathrm{g} / \mathrm{ml}$ [10]. Adianti et al. suggested that glycycoumarin, glycerin, glycerol, and liquiritigenin isolated from Glycyrrhiza uralensis, as well as isoliquiritigenin, licochalcone A, and glabridin, would be good candidates for seed compounds to develop antivirals against HCV [11]. Quercetin and gallic acid isolated from Kalanchoe pinnata inhibited HCV production in a dose-dependent manner with $\mathrm{IC}_{50}$ value of 1.5 and $6.1 \mu \mathrm{g} / \mathrm{ml}$, respectively, without exhibiting cytotoxicity [12]. 
Evaluation of certain Indonesia medicinal plants explored from East Java revealed that Toona sureni is one of the good candidates for the development of anti-HCV drugs. T. sureni (Indonesian mahogany) is a member of Meliaceae family and locally known as suren. The study reported that ethanol extract of $T$. sureni leaves exhibited antiviral activity with $\mathrm{IC}_{50}$ value of $13.9 \pm 1.6 \mu \mathrm{g} / \mathrm{ml}$ against HCV J6/JFH1. Time of addition experiment revealed that the extract inhibited both at the entry and postentry steps. T. sureni leaves extract was not toxic (cytotoxicity concentration $\left[\mathrm{CC}_{50}\right]>500 \mu \mathrm{g} / \mathrm{ml}, \mathrm{SI}>35.9$ ); therefore, further study was taken to investigate the active substances from $T$. sureni leaves extract [13]

Another Toona species has been known for other activity. T. sinensis has activity for antimicrobial, anticancer, anti-inflammation, radical scavenging, and antioxidant in the liver. T. ciliata and T. pubescens have been used traditionally as a treatment for diarrhea, as cardiotonic, astringent, and antioxidant [8,14-18]. However, Jain et al. reported in his research that the antioxidant activity level can affect reduction of chronic hepatitis and cirrhosis [19].

\section{METHODS}

\section{Plant material}

T. sureni leaves were collected from Pujon, East Java, Indonesia. Authentication and identification of plant were carried out at the Purwodadi Botanical Garden, East Java.

\section{Extraction and isolation}

Leaves of T. sureni were dried at room temperature and pulverized. Dried leaves powder ( $250 \mathrm{~g}$ ) were extracted using $80 \%$ ethanol by maceration method. The ethanol extract was filtered and concentrated using rotary evaporator. The crude ethanol extract (25.6 g) was suspended in water and partitioned between chloroform, ethyl acetate, and butanol, successively to obtain chloroform, ethyl acetate, butanol, and water fraction, respectively. Ethylacetate fraction $(8.63 \mathrm{~g})$ was further separated on silica gel column using chloroform-methanol 5\% gradient system resulted in nine sub-fractions (Sub-Fr E1-E9). Sub-Fr E3 was subjected to open column chromatography using silica gel and chloroform-ethyl acetate (1:1) to yield ethyl gallate (1). Sub-Fr E4 was further subjected to silica gel column (chloroform/methanol 90:1-50:50) resulted in nine sub-fractions (Sub-Fr E4.1-E4.9). Sub-Fr E4.1 further subjected to silica gel column (hexane/ethyl acetate 40:60; 20:80, ethyl acetate, and methanol) to yield ethyl gallate (1). Sub-Fr E4.2 was subjected to semi-preparative high-performance liquid chromatography (HPLC) system (C-18 column, $5 \mathrm{um}, 10 \times 250 \mathrm{~mm}$, flow rate $2.5 \mathrm{ml} / \mathrm{min}$ ) using acetonitrile-water (20-80\%) to yield methyl gallate (2). Sub-Fr E4.3 was also subjected to semi-preparative HPLC using the same condition (flow rate $1.5 \mathrm{ml} / \mathrm{min}$ ) to obtain gallic acid (3) and catechin (4). SubFr E4.4 was also subjected to semi-preparative HPLC using the same condition (flow rate $1.5 \mathrm{ml} / \mathrm{min}$ ) to yield quercetin 3-0-rhamnoside (5). Structure elucidation based on nuclear magnetic resonance (NMR) data dan references data. The ${ }^{1} \mathrm{H}$ NMR spectra were measured with JEOL ECA 500 spectrometer (500 MHz), while HPLC was performed on Shimadzu system.

\section{Cells and viruses}

Huh-7.5 cells were cultivated in Dulbecco's modified Eagle's medium supplemented with fetal bovine serum, non-essential amino acids, penicillin, and streptomycin. Cells were grown at $37^{\circ} \mathrm{C}$ in a $5 \% \mathrm{CO}_{2}$ incubator.

\section{Analysis of anti-HCV activities}

T. sureni extract and fractions were dissolved in dimethyl sulfoxide (DMSO) to obtain stock solutions at a concentration of $100 \mathrm{mg} / \mathrm{ml}$. The stock solutions were stored at $-20^{\circ} \mathrm{C}$ until they were used. Analysis of anti-HCV method was described previously $[9,13]$. Huh-7.5 cells were seeded in 24 -well plates (cell density $1.9 \times 10^{5}$ cells/well). A fixed amount of J6/JFH1 with multiplication of infection of 0.5 focus-forming units/cell was mixed with serial dilutions of the extracts $(100,30$, 10,1 , and $0.1 \mu \mathrm{g} / \mathrm{ml}$ ) and inoculated to the cells. After $2 \mathrm{~h}$, the cells were washed with medium to remove the residual virus and further incubated in the medium containing the same concentrations of the test samples as those during virus inoculation.

Culture supernatants were obtained at 2-day postinfection and titrated for virus infectivity. Virus and cells treated with medium containing $0.1 \%$ DMSO served as a control. The inhibition percentage of virus infectivity by the samples was calculated by comparing to the control using SPSS probit analysis, and the $\mathrm{IC}_{50}$ value was determined.

\section{Cytotoxicity assay}

The cytotoxicity of the samples was assessed by WST-1 assay. Huh7.5 cells were seeded in 96-well plates and treated with serial dilution of the samples or control ( $0.1 \%$ DMSO) for $48 \mathrm{~h}$. The condition of cells was observed under microscope to detect the toxic effect on cell morphology. After $48 \mathrm{~h}$, the medium was removed from 96-well plates and then added with $10 \%$ of WST- 1 reagent $(10 \mu \mathrm{l} /$ well $)$ and incubated for $4 \mathrm{~h}$ at $37^{\circ} \mathrm{C}$. The absorbance of samples was measured at $560 \mathrm{~nm}$ and $750 \mathrm{~nm}$. Cell viability percentage and $50 \% \mathrm{CC}_{50}$ were calculated.

\section{RESULTS AND DISCUSSION}

Bioactivity-guided isolation of anti-HCV compounds from T. sureni was conducted using Huh-7.5 cells infected with HCV J6/JFH1 in the presence of extract, fractions, or compounds from the plant. To isolate an active substance(s) responsible for the anti-HCV activity, the crude ethanol extract was partitioned into chloroform (Fr C), ethyl acetate (Fr E), butanol (Fr B), and water fractions (Fr W), and their anti-HCV activities were evaluated. The result showed that the Fr C and Fr E had strong anti-HCV activities with $\mathrm{IC}_{50}$ values of 1.6 and $1.7 \mu \mathrm{g} / \mathrm{ml}$, respectively (Table 1 ).

Due to the anti-HCV activities of Fr E, further separation of Fr E was done by open column chromatography and resulted in nine subfractions (Sub-Fr E1-E9). These fractions were evaluated for anti-HCV and cytotoxic activities. The result obtained revealed that sub-Fr E3 and E4 have strong anti-HCV activities with IC $_{50}$ value of $29.9 \mu \mathrm{g} / \mathrm{ml}$ and $7.7 \mu \mathrm{g} / \mathrm{ml}$, respectively (Table 2 ).

Sub-Fr E3 and E4 were subjected to further purification which yielded some polyphenols compounds that have been determined to be ethyl gallate (1), methyl gallate (2), catechin (3), gallic acid (4), and quercetin 3-0-rhamnoside (5) (Fig. 1). Chemical structures of isolated compounds were elucidated based on NMR spectroscopy and reference

Table 1: $\mathrm{IC}_{50}$ values of a crude ethanol extract and its fractions from $T$. sureni

\begin{tabular}{ll}
\hline Samples & $\mathbf{I C}_{50}, \boldsymbol{\mu g} / \mathbf{m l}$ \\
\hline Ethanol extract & 13.9 \\
Chloroform fraction (Fr C) & 1.6 \\
Ethyl acetate fraction (Fr E) & 1.7 \\
Butanol fraction (Fr B) & 15.4 \\
Water fraction (Fr W) & 50.0 \\
\hline
\end{tabular}

T. sureni: Toona sureni, $\mathrm{IC}_{50}: 50 \%$ inhibitory concentration

Table 2: $\mathrm{IC}_{50}$ values of Fr E fractions from T. Sureni

\begin{tabular}{ll}
\hline Samples & IC $_{\mathbf{5 0}}, \boldsymbol{\mu g} / \mathbf{m l}$ \\
\hline E1 & $\mathrm{NT}$ \\
E2 & $\mathrm{NT}$ \\
E3 & $29.9 \pm 0.7$ \\
E4 & $7.7 \pm 0.2$ \\
E5 & $27.0 \pm 4.2$ \\
E6 & $7.1 \pm 0.3$ \\
E7 & $16.8 \pm 0.3$ \\
E8 & $7.4 \pm 0.2$ \\
E9 & $16.6 \pm 0.1$ \\
\hline *NT: Not tested. sureni: Toona sureni $1 \mathrm{C} .50 \%$ inhibitory concentration
\end{tabular}

*NT: Not tested. T. sureni: Toona sureni, $\mathrm{IC}_{50}: 50 \%$ inhibitory concentration 
<smiles>CCOC(=O)c1cc(O)c(O)c(O)c1</smiles>

Fig. 1: Chemical structure of isolated compounds from sub-Fr E3 and E4 of Toona sureni

Table 3: $\mathrm{IC}_{50}$ values of isolates from sub-Fr E3 and E4 T. Sureni

\begin{tabular}{lll}
\hline Samples & $\mathbf{I C}_{\mathbf{5 0}}, \boldsymbol{\mu g} / \mathbf{m L}$ & $\mathbf{C C}_{\mathbf{5 0}}, \boldsymbol{\mu g} / \mathbf{m L}$ \\
\hline Ethyl gallate & $52.5 \pm 3.5$ & $>100$ \\
Methyl gallate & $>100$ & $>100$ \\
Gallic acid & $15.9 \pm 0.2$ & $>100$ \\
Catechin & $52.0 \pm 4.9$ & $>100$ \\
Quercetin 3-0-rhamnoside & $>100$ & $>100$ \\
\hline
\end{tabular}

T. sureni: Toona sureni, $\mathrm{IC}_{50}: 50 \%$ inhibitory concentration, $\mathrm{CC}_{50}$ : Cytotoxicity concentration

data. Anti-HCV activities of those compounds were then evaluated. The results showed that gallic acid mediates a strong anti-HCV activity with $\mathrm{IC}_{50}$ value of $15.90 \mu \mathrm{g} / \mathrm{ml}$, while ethyl gallate and catechin revealed moderate activities with $\mathrm{IC}_{50}$ value of 52.5 and $52.0 \mu \mathrm{g} / \mathrm{ml}$, respectively. On the other hand, the presence of methyl moiety in the methyl gallate resulting inactive compound against $\mathrm{HCV}$, suggesting that moiety of $\mathrm{OH}$ in gallic acid may play an important role for its anti-HCV activities (Table 3).

Gallic acid is also a common natural constituent of a variety of plants. In the present study, gallic acid was identified as a compound with stronger anti-HCV activity than the other isolated compounds. According to Hsu et al. reported that gallic acid inhibits HCV in the entry step. This compound inactivates cell-free viral particle and blocks its attachment to the host cells. However, it has a little effect on postbinding of viral entry and fusion stage [20]. Gallic acid is also known to have antioxidant and hepatoprotective activities [21,22]. Most phenolic compounds have radical-scavenging activity. The activity depends on the number and position of hydroxyl group substituent in the molecules as which called on the antioxidant activity of flavonoids is known to be associated with the number of free hydroxyl groups [23]. Jain et al. also reported in his research that the antioxidant activity level can affect reduction of chronic hepatitis and cirrhosis [19]. It is conceivable, therefore, that the anti-HCV mechanism of gallic acid involves its antioxidant activities. Other researchers reported that polyphenols like gallic acid were responsible for the anti-HCV activity in plants [24]. Recent study showed that gallic acid decreases the HCV expression through its antioxidant activities. Gallic acid reduced the level of reactive oxygen species generated by strong oxidizing agent, such as $\mathrm{H}_{2} \mathrm{O}_{2}$, which could inhibit viral replication. This compound attenuates the translation rate of viral proteins or decreases the stability of viral protein [25]. Moreover, gallic acid was reported to inhibit several other viruses such as influenza virus, foodborne viral surrogates, murine norovirus-1, and feline calicivirus-F9 $[26,27]$. The antiviral activities of gallic acid might be caused by the hydrophobic interaction between the functional group (hydroxyl) and virion components, bind to free radicals and exert an antioxidant effect [25].

\section{CONCLUSION}

Plant of T. sureni is a potential source for anti-HCV agent. Ethyl acetate fraction (Fr E) of this plant is active as anti-HCV against J6/JFH1 with $\mathrm{IC}_{50}$ value of $1.7 \mu \mathrm{g} / \mathrm{ml}$. Ethyl gallate (1), methyl gallate (2), catechin (3), gallic acid (4), and quercetin 3-0-rhamnoside (5) were isolated from Fr E. Among the isolated compounds; gallic acid showed to possess strong anti-HCV activity with $\mathrm{IC}_{50}$ value of $15.9 \mu \mathrm{g} / \mathrm{ml}$. These results suggested that T. sureni and its isolated compound, gallic acid, may be good candidates to develop for alternative and/or complementary agents of anti-HCV infection.

\section{ACKNOWLEDGMENTS}

This study was supported by grant for Research Project Collaboration of Science and Technology Research Partnership for Sustainable Development (SATREPS) from Japan Science and Technology Agency (JST), Japan International Cooperation Agency (JICA) and Universitas Airlangga, Indonesia, year 2010-2014.

\section{AUTHOR CONTRIBUTION}

AFH, LT, AW, HF and NK contributed to phytochemistry work. TSW, EA, AAP, MA and CAU contributed to anti-HCV work. MIL, S and HH as principle investigators, planned and coordinated the study. All the authors read and approved the final manuscript.

\section{CONFLICT OF INTEREST}

The authors declare that they have no conflict of interest.

\section{REFERENCES}

1. Shepard CW, Finelli L, Alter MJ. Global epidemiology of hepatitis C virus infection. Lancet Infect Dis 2005;5:558-67.

2. Holtzman D. Infectious Disease Related to Travel; 2015. Available from: http://www.nc.cdc.gov/travel/yellowbook/2014/ chapter3infectiousdiseaserelatedtotravel/hepatitisC.

3. Rupp D, Bartenschlager R. Targets for antiviral therapy of hepatitis C. Semin Liver Dis 2014;34:9-21.

4. Moradpour D, Penin F, Rice CM. Replication of hepatitis C virus. Nat Rev Microbiol 2007;5:453-63.

5. Lange CM, Jacobson IM, Rice CM, Zeuzem S. Emerging therapies for the treatment of hepatitis C. EMBO Mol Med 2014;6:4-15.

6. Wahyuni TS, Aoki C, Hotta H. Promising anti-virus hepatitis C compounds from natural resources. Nat Prod Commun 2016;11:1193-200.

7. Polamreddy P, Vishwakarma V, Gundla R. A review on anti-HCV agents targetting active site and allosteric sites of non-structural protein 5B (NS5B). Int J Pharm Pharm Sci 2016;8:1-18.

8. Kumar SR, Kumar D, Kashyap D, Rana M. A mini review on the phytochemistry and pharmacological activities of the plant Toona ciliata (Meliaceae). Int J Pharm Res 2012;1:62-72.

9. Wahyuni TS, Tumewu L, Permanasari AA, Apriani E, Adianti M, Rahman A, et al. Antiviral activities of Indonesian medicinal plants in the East Java region against hepatitis C virus. Virol J 2013;10:259.

10. Ratnoglik SL, Aoki C, Sudarmono P, Komoto M, Deng L, Shoji I, 
et al. Antiviral activity of extracts from Morinda citrifolia leaves and chlorophyll catabolites, pheophorbide a and pyropheophorbide a, against hepatitis C virus. Microbiol Immunol 2014;58:188-94.

11. Adianti M, Aoki C, Komoto M, Deng L, Shoji I, Wahyuni TS, et al. Anti-hepatitis C virus compounds obtained from Glycyrrhiza uralensis and other Glycyrrhiza species. Microbiol Immunol 2014;58:180-7.

12. Aoki C, Hartati S, Santi MR, Lydwina T, Firdaus R, Hanafi M, et al. Isolation and identification of substances with anti-hepatitis $\mathrm{C}$ virus activities from Kalanchoe pinnata. Int J Pharm Pharm Sci 2014;6:211-5.

13. Wahyuni TS, Widyawaruyanti A, Lusida MI, Fuad A, Soetjipto, Fuchino $\mathrm{H}$, et al. Inhibition of hepatitis $\mathrm{C}$ virus replication by chalepin and pseudane IX isolated from Ruta angustifolia leaves. Fitoterapia 2014;99:276-83

14. Wu JG, Peng W, Yi J, Wu YB, Chen TQ, Wong KH, et al. Chemical composition, antimicrobial activity against Staphylococcus aureus and a pro-apoptotic effect in SGC-7901 of the essential oil from Toona sinensis (A. Juss.) Roem. leaves. J Ethnopharmacol 2014;154:198-205.

15. Hsieh TJ, Tsai YH, Liao MC, Du YC, Lien PJ, Sun CC, et al. Antidiabetic properties of non-polar Toona sinensis Roem extract prepared by supercritical-CO2 fluid. Food Chem Toxicol 2012;50:779-89.

16. Chen HM, Wu YC, Chia YC, Chang FR, Hsu HK, Hsieh YC, et al. Gallic acid, a major component of Toona sinensis leaf extracts, contains a ROS-mediated anti-cancer activity in human prostate cancer cells. Cancer Lett 2009;286:161-71.

17. Yang MS, Hu SM, Kong LY, Luo J. B-seco-29-nor-limonoids from the stem barks of Toona ciliate var. Yunnanensis. Tetrahedron 2015;10:8472-7.

18. Zhang W, Li C, You LJ. Structural identification of compounds from Toona sinensis leaves with antioxidant and anticancer activities. J Funct
Foods 2014;10:427-35.

19. Jain SK, Pemberton PW, Smith A, McMahon RF, Burrows PC, Aboutwerat A, et al. Oxidative stress in chronic hepatitis C: Not just a feature of late stage disease. J Hepatol 2002;36:805-11

20. Hsu WC, Chang SP, Lin LC, Li CL, Richardson CD, Lin CC, et al. Limonium sinense and gallic acid suppress hepatitis $\mathrm{C}$ virus infection by blocking early viral entry. Antiviral Res 2015;118:139-47.

21. Kubo I, Masuoka N, Xiao P, Haraguchi H. Antioxidant activity of dodecyl gallate. J Agric Food Chem 2002;50:3533-9.

22. Rasool MK, Sabina EP, Ramya SR, Preety P, Patel S, Mandal N, et al. Hepatoprotective and antioxidant effects of gallic acid in paracetamolinduced liver damage in mice. J Pharm Pharmacol 2010;62:638-43.

23. Hamed MM, Refahy LA, Abdel-Aziz MS. Assessing the bioactivity and antioxidative properties of some compounds isolated from Abutilon hirtum Lam.). Asian J Pharm Clin Res 2017;10:333-40.

24. Zuo GY, Li ZQ, Chen LR, Xu XJ. In vitro anti-HCV activities of Saxifraga melanocentra and its related polyphenolic compounds. Antivir Chem Chemother 2005; 16:393-8.

25. Govea-Salas M, Rivas-Estilla AM, Rodríguez-Herrera R, Lozano-Sepúlveda SA, Aguilar-Gonzalez CN, Zugasti-Cruz A, et al. Gallic acid decreases hepatitis $\mathrm{C}$ virus expression through its antioxidant capacity. Exp Ther Med 2016;11:619-24.

26. Lee JH, Bae SY, Oh M, Seok JH, Kim S, Chung YB, et al. Antiviral effects of black raspberry (Rubus coreanus) seed extract and its polyphenolic compounds on norovirus surrogates. Biosci Biotechnol Biochem 2016;80:1196-204.

27. Enkhtaivan G, Maria John KM, Ayyanar M, Sekar T, Jin KJ, Kim DH. Anti-influenza (H1N1) potential of leaf and stem bark extracts of selected medicinal plants of South India. Saudi J Biol Sci 2015;22:532-8. 